\title{
Importance of gender-specific calcitonin thresholds in screening for occult sporadic medullary thyroid cancer
}

\author{
Andreas Machens*, Florian Hoffmann*, Carsten Sekulla and Henning Dralle \\ Department of General, Visceral and Vascular Surgery, Martin Luther University Halle-Wittenberg, Ernst-Grube-Straße 40, D-06097 \\ Halle (Saale), Germany \\ (Correspondence should be addressed to A Machens; Email: andreasmachens@aol.com) \\ *(A Machens and $F$ Hoffmann contributed equally to this work)
}

\begin{abstract}
Men and women differ in thyroidal C-cell mass and calcitonin secretion. This difference may have implications for the definition of calcitonin thresholds to distinguish sporadic C-cell hyperplasia from occult medullary thyroid cancer. This retrospective study examined the hypothesis that gender-specific calcitonin thresholds predict occult medullary thyroid cancer more accurately among patients with increased basal calcitonin levels than unisex thresholds. A total of 100 consecutive patients were evaluated with occult sporadic C-cell disease no larger than $10 \mathrm{~mm}$ who were referred for increased basal calcitonin levels and underwent pentagastrin stimulation preoperatively at this institution. Altogether, gender-specific calcitonin thresholds predicted medullary thyroid cancer better than unisex thresholds. At lower ( $\leq 50 \mathrm{pg} / \mathrm{ml}$ basally; $\leq 500 \mathrm{pg} / \mathrm{ml}$ after stimulation), but not higher, calcitonin serum levels, women revealed medullary thyroid cancer four to eight times more often than men. Most discriminatory between C-cell hyperplasia and medullary thyroid cancer was a basal calcitonin threshold of $15 \mathrm{pg} / \mathrm{ml}$ (corrected $20 \mathrm{pg} / \mathrm{ml}$ ) for women and $80 \mathrm{pg} / \mathrm{ml}$ (corrected $100 \mathrm{pg} / \mathrm{ml}$ ) for men, based on the greatest accuracy at the lowest possible calcitonin level. The respective gender-specific stimulated peak calcitonin thresholds were $80 \mathrm{pg} / \mathrm{ml}$ (corrected $100 \mathrm{pg} / \mathrm{ml}$ ) and $500 \mathrm{pg} / \mathrm{ml}$. Corresponding positive predictive values for medullary thyroid cancer at these calcitonin thresholds were 89 and $90 \%$ for women, as opposed to $100 \%$ for men. To increase the positive predictive value for women to $100 \%$, the respective calcitonin thresholds would have to be raised to $40 \mathrm{pg} / \mathrm{ml}$ (corrected $50 \mathrm{pg} / \mathrm{ml}$ ) and $250 \mathrm{pg} / \mathrm{ml}$. These findings indicate that gender-specific calcitonin thresholds predict sporadic occult medullary thyroid cancer better than unisex thresholds.
\end{abstract}

Endocrine-Related Cancer (2009) 16 1291-1298

\section{Introduction}

Originating from parafollicular C-cells, medullary thyroid cancer cells retain the ability of synthesizing, storing, and releasing calcitonin into the bloodstream. Because they broadly reflect overall C-cell mass (Iacobone et al. 2002, Machens et al. 2005), serum calcitonin levels have prognostic ramifications in medullary thyroid cancer patients regarding a) the extent of locoregional disease and neck dissection preoperatively, and b) locoregional recurrence and cancer-specific survival postoperatively (Machens et al. 2007, Oskam et al. 2008).
With the propagation of calcitonin screening, the prevalence of medullary thyroid cancer has surged from 1.1 to 3.2 cases per 1000 patients with nodular thyroid disease (Vierhapper et al. 2005). This increase was mainly due to the increasing detection of occult medullary thyroid cancer no larger than $10 \mathrm{~mm}$. In the presence of multinodular goiter, these occult cancers are barely amenable to conventional diagnostic strategies, such as ultrasonographic visualization and fine-needle aspiration. Because occult medullary thyroid cancers are usually still confined to the thyroid gland without having spread to lymph nodes, total thyroidectomy usually will be curative at this early 
stage (Elisei et al. 2004). In contrast, surgical cure is exceptional with larger tumors when 10 or more lymph nodes are involved (Machens et al. 2000a, Scollo et al. 2003).

As in any other screening program, the costeffectiveness of calcitonin screening for medullary thyroid cancer hinges on a) the prevalence of the target disease (3.2 cases per 1000 patients with thyroid nodular disease), b) the predictive value of the screening test (which depends on the calcitonin threshold selected), and c) the availability of effective treatment strategies (e.g. thyroidectomy that will cure all cancers limited to the thyroid gland). For these reasons, calcitonin screening holds great promise as a cost-effective screening tool.

The most common alternative source of calcitonin secretion, other than medullary thyroid cancer, is C-cell hyperplasia, which also arises from the parafollicular C-cells of the thyroid gland. It comes in a reactive (sporadic) and a neoplastic (hereditary) variety. Unlike its reactive counterpart, hereditary neoplastic C-cell hyperplasia represents a preneoplastic condition for carriers of rearranged during transfection (RET) germline mutations, giving rise to hereditary medullary thyroid cancer in an agedependent fashion (Machens et al. 2003). Because increased calcitonin serum levels can originate from either condition, it is often challenging, if not impossible, to distinguish $\mathrm{C}$-cell hyperplasia from medullary thyroid cancer, especially at lower levels.

Strictly speaking, both C-cell hyperplasia patients and medullary thyroid cancer patients, revealing elevated calcitonin serum levels, yield 'positive' calcitonin test results. Yet, the ramifications of a positive calcitonin test differ greatly depending on the underlying condition: from expectant observation, or total thyroidectomy without any form of lymph node dissection, for sporadic C-cell hyperplasia to immediate total thyroidectomy, usually coupled with systematic lymph node dissection of at least the central neck compartment, for medullary thyroid cancer. To make this important distinction, biochemical screening programs for medullary thyroid cancer commonly have interpreted increased calcitonin serum levels as true positive in the presence of medullary thyroid cancer, and as false positive in the absence thereof. Indeed, such false-positive test results, mostly in connection with lower calcitonin levels, have tarnished the performance of calcitonin screening, triggering unnecessary thyroid operations for suspected but non-existent medullary thyroid cancer. For instance, the failure to define gender-specific calcitonin thresholds may have diminished the assay's performance by covering up gender-specific differences in thyroid C-cell mass and calcitonin secretion (Heath \& Sizemore 1977).

False-negative findings may have resulted from the inclusion of patients with medullary thyroid cancer $>10 \mathrm{~mm}$. This inclusion may have raised calcitonin thresholds so much that some patients with smaller medullary thyroid cancer became misclassified as tumor free. These gross tumors are often detectable using conventional methods, rendering the case for biochemical detection less compelling. Moreover, the unwillingness of some patients with increased calcitonin levels to undergo thyroidectomy may have caused underestimation of medullary thyroid cancer prevalence (Heath \& Sizemore 1977, Vierhapper et al. 2005).

The current investigation aimed to examine the hypothesis that gender-specific calcitonin thresholds predict occult medullary thyroid cancer better than unisex thresholds in patients with sporadic C-cell disease.

\section{Patients and methods}

\section{Inclusion and exclusion criteria}

To be considered for this retrospective study, patients needed to have undergone total thyroidectomy with or without systematic lymph node dissection at this institution, in addition to meeting the following criteria:

(a) an increased basal calcitonin level stimulated preoperatively by i.v. bolus injection of $0.5 \mu \mathrm{g}$ pentagastrin (Peptavlon, Laboratoires SERB, Paris, France) per kilogram body weight, measured at this institution between July 2004 and December 2008 with the Immulite 2000 calcitonin assay (Diagnostic Products Corporation, Los Angeles, CA, USA; normal range $<5 \mathrm{pg} / \mathrm{ml}$ for women and $<8.4 \mathrm{pg} / \mathrm{ml}$ for men; or $<5$ and $<8.4 \mathrm{ng} / \mathrm{l}$ respectively in Système International Units). The Immulite 2000 automated calcitonin assay, instituted in July 2004 to enable determination of calcitonin levels immediately before surgery, is linearly related to other calcitonin assays, including the Nichols Advantage assay, but with a lower calibration relative to other calcitonin assays (Bieglmayer et al. 2007). This is most relevant for serum calcitonin levels $<100 \mathrm{pg} / \mathrm{ml}$. Bieglmayer et al. (2007) proposed to use a conversion factor of 0.8 for the transformation of calcitonin levels measured 
with other calcitonin assays into calcitonin levels obtained with the Immulite 2000 system. For the reverse calculation, the suggested conversion factor was 1.25 (or $1 / 0.8$ ), which henceforth is referred to as the Bieglmayer correction;

(b) a histopathologic diagnosis of C-cell hyperplasia based on at least $>50 \mathrm{C}$-cells per low-power field $(\times 100)$ or medullary thyroid cancer (breach of the basement membrane) confined to the thyroid gland no larger than $10 \mathrm{~mm}$ in greatest dimension;

(c) negative personal histories of bronchial cancer (Machens et al. 2000b), neuroendocrine cancer (Machens et al. 2000b), renal failure, hyperparathyroidism, follicular cell-derived thyroid cancer, proton pump inhibitors, or any other drug known to increase serum calcitonin levels (Karges et al. 2004, Borget et al. 2007);

(d) a negative RET gene test for exons 10, 11, 13, 14, 15 , and 16 (all medullary thyroid cancer patients); exon 8 was not tested in all these patients;

(e) negative family histories of medullary thyroid cancer, pheochromocytoma, or hyperparathyroidism.

\section{Thyroidectomy and cervical lymph node dissection}

Fulfilling all these criteria, 100 consecutive patients (74 men and 26 women) qualified for this analysis. In addition to thyroidectomy, $51(51 \%)$ of these patients underwent central lymph node dissections (24 of 26 medullary thyroid cancer and 27 out of $74 \mathrm{C}$-cell hyperplasia patients), and 23 (23\%) patients underwent lateral lymph node dissections for medullary thyroid cancer at the operating surgeon's discretion. Surgical procedures were conducted using optical magnification and bipolar coagulation, as described elsewhere (Dralle 2002). Informed consent was obtained before each surgical procedure that represented standard practice of care.

\section{Pathological examination and tumor staging}

A total of 100 entire thyroid glands were available for histopathologic examination. After gross evaluation by the pathologist, the entire thyroid gland was divided vertically to separate the left and right lobes. The thyroid halves were then sectioned horizontally from the superior to the inferior pole, as previously described (Hinze et al. 1998). After fixation in formalin, the whole thyroid gland was embedded in paraffin. Soft tissue and lymph nodes were processed separately. Conventional staining (hematoxylin and eosin) and calcitonin immunohistochemistry were performed on every surgical specimen, using the standard avidin-biotin complex peroxidase approach and a commercial polyclonal antibody (Immunotech, Marseilles, France). A diagnosis of medullary thyroid cancer was made on evidence of tumor extension beyond the basement membrane, demonstration of lymphatic or vascular invasion on histopathology, or any combination thereof. Primary tumor diameter was ascertained by direct measurements on the surgical thyroid specimens. Histopathologic confirmation was required for diagnosis of lymph node metastasis.

\section{Statistical analysis}

Categorical and continuous data were tested with the two-tailed Fisher exact test and Mann-WhitneyWilcoxon rank sum test respectively. Multiple testing was corrected with the Bonferroni method. Suitability for prediction of medullary thyroid cancer was evaluated using receiver operating characteristics (ROC) curves. The level of significance was set at $<0.05$.

\section{Results \\ Study population}

As depicted in Table 1, 26 patients harbored occult solitary medullary thyroid cancer, one of which was node positive (one positive among 104 removed nodes). These 26 medullary thyroid cancer patients differed significantly $(P<0.001)$ from the $74 \mathrm{C}$-cell hyperplasia patients regarding the prevalence of concomitant goiter (35 vs 76\%), basal and stimulated peak calcitonin levels (respective means of 85 vs 19 , and 1519 vs $116 \mathrm{pg} / \mathrm{ml}$ ), the ratio of stimulated peak calcitonin to basal calcitonin serum levels (respective means of 22-fold versus sixfold), and underrepresentation of men (31 vs $89 \%$ ). No significant differences were found among the two groups with regard to age, histopathologic presence of thyroiditis, or postoperative normalization of calcitonin levels (biochemical cure).

\section{ROC curves}

ROC plot analyses (not shown) confirmed the superiority of stimulated over basal calcitonin levels for prediction of medullary thyroid cancer, with mean areas under the curve totaling 0.89 and 0.74 respectively. The fit was better for women $(0.99$ and 0.85$)$ than men (0.71 and 0.53). 


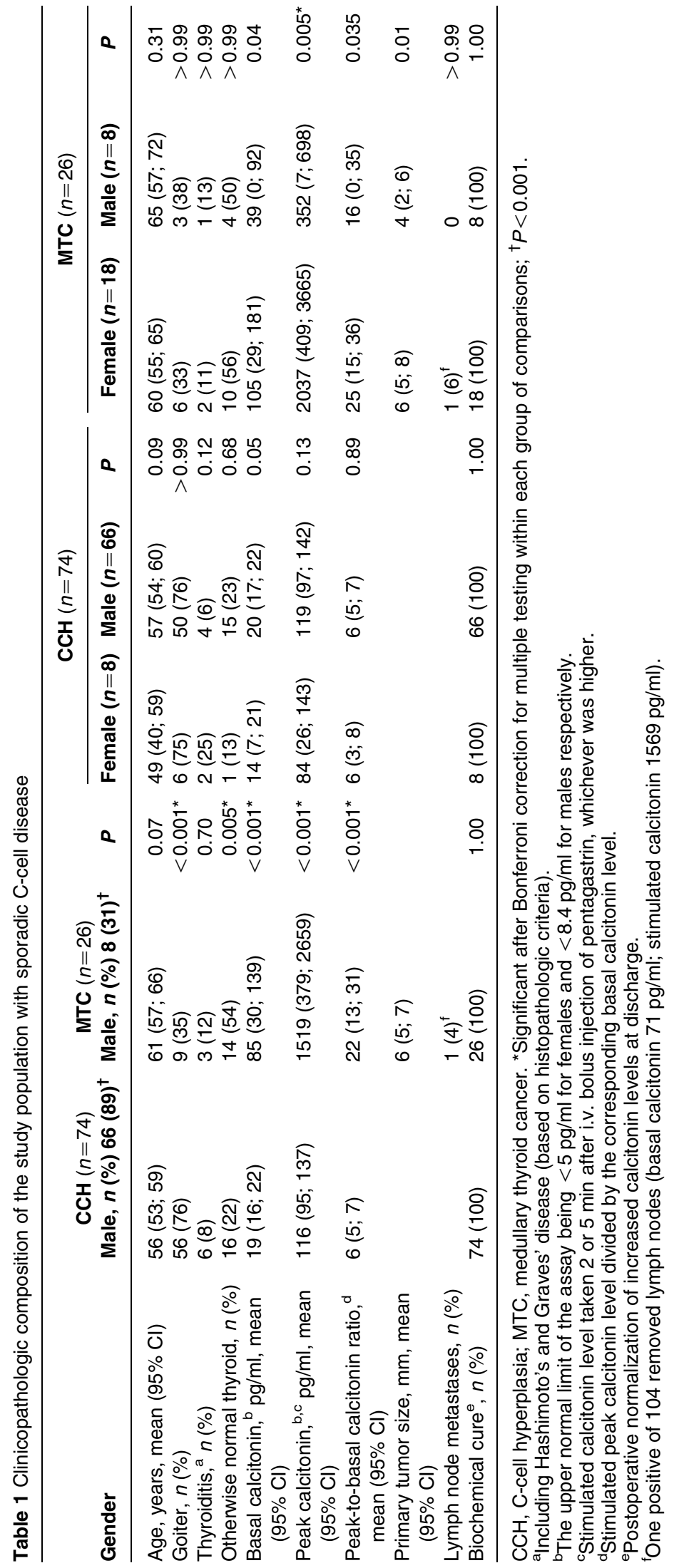


Table 2 Prevalence and tumor size of medullary thyroid cancer by preoperative calcitonin level

\begin{tabular}{|c|c|c|c|c|c|c|c|c|c|c|}
\hline \multirow[b]{2}{*}{$\begin{array}{l}\text { Serum } \\
\text { calcitonin }^{a}\end{array}$} & \multirow[b]{2}{*}{$\mathrm{pg} / \mathrm{ml}$} & \multicolumn{3}{|c|}{ Female $(n=26)$} & \multicolumn{3}{|c|}{ Male $(n=74)$} & \multicolumn{3}{|c|}{ Total $(n=100)$} \\
\hline & & $\begin{array}{c}\text { Total, } \\
n\end{array}$ & $\begin{array}{l}\text { MTC, } \\
n(\%)\end{array}$ & $\begin{array}{l}\text { Size, mm, } \\
\text { median } \\
\text { (range) }\end{array}$ & $\begin{array}{c}\text { Total, } \\
n\end{array}$ & $\begin{array}{l}\text { MTC, } \\
n(\%)\end{array}$ & $\begin{array}{l}\text { Size, mm, } \\
\text { median } \\
\text { (range) }\end{array}$ & $\begin{array}{c}\text { Total, } \\
n\end{array}$ & $\begin{array}{l}\text { MTC, } \\
n(\%)\end{array}$ & $\begin{array}{l}\text { Size, mm, } \\
\text { median } \\
\text { (range) }\end{array}$ \\
\hline \multirow[t]{4}{*}{ Basal } & $\leq 20$ & 11 & $4(36)$ & $7(2-8)$ & 52 & $5(10)$ & $4(2-5)$ & 63 & $9(14)$ & $4(2-8)$ \\
\hline & $21-50$ & 5 & $4(80)$ & $6(4-6)$ & 19 & $2(11)$ & $3(2-4)$ & 24 & $6(25)$ & $6(2-10)$ \\
\hline & $51-100$ & 6 & $6(100)^{b}$ & $6(2-9)$ & 2 & 0 & & 8 & $6(75)^{\mathrm{b}}$ & $6(2-9)$ \\
\hline & $>100$ & 4 & $4(100)$ & $10(9-10)$ & 1 & $1(100)$ & 8 & 5 & 5 (100) & $9(8-10)$ \\
\hline \multirow[t]{4}{*}{ Peak $^{c}$} & $\leq 100$ & 6 & 0 & & 39 & $3(8)$ & $2(2-4)$ & 45 & $3(7)$ & $2(2-4)$ \\
\hline & $101-500$ & 8 & $6(75)$ & $6(2-8)$ & 33 & $3(9)$ & $4(2-5)$ & 41 & $9(22)$ & $5(2-8)$ \\
\hline & $501-1000$ & 3 & $3(100)$ & $5(4-6)$ & 1 & $1(100)$ & 4 & 4 & $4(100)$ & $5(4-6)$ \\
\hline & $>1000$ & 9 & $9(100)^{b}$ & $9(5-10)$ & 1 & $1(100)$ & 8 & 10 & $10(100)^{b}$ & $9(5-10)$ \\
\hline
\end{tabular}

MTC, medullary thyroid cancer.

${ }^{a}$ The upper normal limit of the assay being $<5 \mathrm{pg} / \mathrm{ml}$ for females and $<8.4 \mathrm{pg} / \mathrm{ml}$ for males respectively.

${ }^{b}$ One of which was node positive (one positive of 104 removed lymph nodes; basal calcitonin $71 \mathrm{pg} / \mathrm{ml}$; stimulated calcitonin $1569 \mathrm{pg} / \mathrm{ml})$.

${ }^{\mathrm{c}}$ Stimulated calcitonin level taken 2 or $5 \mathrm{~min}$ after i.v. bolus injection of pentagastrin, whichever was higher.

\section{Prevalence of medullary thyroid cancer by preoperative calcitonin level}

The prevalence of sporadic medullary thyroid cancer in women and men increased across the various segments of calcitonin levels (Table 2). Altogether, genderspecific calcitonin thresholds predicted sporadic medullary thyroid cancer better than unisex thresholds. Intriguingly, women revealed occult medullary thyroid cancer four to eight times more often than men in the lower calcitonin segments (Table 2): 36 vs 10\% (increased basal levels of $<20 \mathrm{pg} / \mathrm{ml}$ ); 80 vs $11 \%$ (basal levels of 21-50 pg/ml) and $75 \mathrm{vs} 9 \%$ (stimulated levels of $101-500 \mathrm{pg} / \mathrm{ml}$ ). In the higher segments, this difference disappeared after levels exceeded $100 \mathrm{pg} / \mathrm{ml}$ (basal calcitonin) and $500 \mathrm{pg} / \mathrm{ml}$ (stimulated calcitonin) respectively. Because tumors larger than $10 \mathrm{~mm}$ were excluded, fewer occult medullary thyroid cancers were seen with higher calcitonin levels.

\section{Sensitivity, specificity, positive and negative predictive value, and accuracy for medullary thyroid cancer}

Sensitivity, specificity, positive and negative predictive value, and accuracy of various calcitonin thresholds were calculated to explore the impact of these gender-specific disparities on the prediction of medullary thyroid cancer. Most discriminatory between C-cell hyperplasia and medullary thyroid cancer was a basal calcitonin threshold of $15 \mathrm{pg} / \mathrm{ml}$ $(20 \mathrm{pg} / \mathrm{ml}$ after Bieglmayer correction) for women and $80 \mathrm{pg} / \mathrm{ml}$ (corrected $100 \mathrm{pg} / \mathrm{ml}$ ) for men, based on the greatest accuracy at the lowest possible calcitonin level (Table 3). The corresponding stimulated peak calcitonin thresholds were $80 \mathrm{pg} / \mathrm{ml}$ (corrected 100) for women and $500 \mathrm{pg} / \mathrm{ml}$ for men (Table 4).

These basal and stimulated peak calcitonin thresholds, however, were not ideal for women because

Table 3 Sensitivity, specificity, positive and negative predictive value, and accuracy of basal calcitonin levels for medullary thyroid cancer

\begin{tabular}{|c|c|c|c|c|c|c|c|c|c|c|}
\hline \multirow{4}{*}{$\begin{array}{l}\text { Immulite } 2000 \text { assay } \\
\text { Bieglmayer corrected }(\times 1.25)^{a}\end{array}$} & \multicolumn{5}{|c|}{ Female $(n=26)$} & \multicolumn{5}{|c|}{ Male $(n=74)$} \\
\hline & \multicolumn{5}{|c|}{ Basal calcitonin threshold (pg/ml) } & \multicolumn{5}{|c|}{ Basal calcitonin threshold (pg/ml) } \\
\hline & 10 & 15 & 20 & 40 & 80 & 20 & 40 & 60 & 80 & 100 \\
\hline & 10 & 20 & 25 & 50 & 100 & 25 & 50 & 75 & 100 & $(125)$ \\
\hline Sensitivity (\%) & 89 & 89 & 83 & 67 & 33 & 50 & 13 & 13 & 13 & 13 \\
\hline Specificity (\%) & 25 & 75 & 75 & 100 & 100 & 65 & 96 & 99 & 100 & 100 \\
\hline Positive predictive value (\%) & 73 & 89 & 88 & 100 & 100 & 15 & 25 & 50 & 100 & 100 \\
\hline Negative predictive value (\%) & 50 & 75 & 67 & 57 & 40 & 92 & 90 & 90 & 90 & 90 \\
\hline Accuracy (\%) & 69 & 85 & 81 & 77 & 54 & 64 & 87 & 89 & 91 & 91 \\
\hline
\end{tabular}

${ }^{a}$ Conversion factor proposed by Bieglmayer et al. (2007), which may be less relevant for calcitonin concentrations $>100 \mathrm{pg} / \mathrm{ml}$. Converted calcitonin levels $>100 \mathrm{pg} / \mathrm{ml}$ are parenthesized to indicate this fact. 
Table 4 Sensitivity, specificity, positive and negative predictive value, and accuracy of stimulated peak calcitonin levels for medullary thyroid cancer

\begin{tabular}{|c|c|c|c|c|c|c|c|c|c|c|}
\hline \multirow[b]{3}{*}{$\begin{array}{l}\text { Immulite } 2000 \text { assay } \\
\text { Bieglmayer corrected }(\times 1.25)^{b}\end{array}$} & \multicolumn{5}{|c|}{ Female $(n=26)$} & \multicolumn{5}{|c|}{ Male $(n=74)$} \\
\hline & \multicolumn{5}{|c|}{$\begin{array}{c}\text { Stimulated peak calcitonin } \\
\text { threshold }(\mathrm{pg} / \mathrm{ml})^{\mathrm{a}}\end{array}$} & \multicolumn{5}{|c|}{$\begin{array}{l}\text { Stimulated peak calcitonin } \\
\text { threshold }(\mathrm{pg} / \mathrm{ml})^{\mathrm{a}}\end{array}$} \\
\hline & $\begin{array}{l}60 \\
75\end{array}$ & $\begin{array}{r}80 \\
100\end{array}$ & $\begin{array}{l}200 \\
(250)\end{array}$ & $\begin{array}{l}250 \\
(300)\end{array}$ & $\begin{array}{l}400 \\
(500)\end{array}$ & $\begin{array}{l}100 \\
(125)\end{array}$ & $\begin{array}{l}200 \\
(250)\end{array}$ & $\begin{array}{l}400 \\
(500)\end{array}$ & $\begin{array}{l}500 \\
(600)\end{array}$ & $\begin{array}{l}800 \\
(1000)\end{array}$ \\
\hline Sensitivity (\%) & 100 & 100 & 94 & 89 & 72 & 63 & 38 & 25 & 25 & 25 \\
\hline Specificity (\%) & 63 & 75 & 88 & 100 & 100 & 53 & 85 & 97 & 100 & 100 \\
\hline Positive predictive value (\%) & 86 & 90 & 94 & 100 & 100 & 14 & 23 & 50 & 100 & 100 \\
\hline Negative predictive value (\%) & 100 & 100 & 88 & 80 & 62 & 92 & 92 & 91 & 92 & 92 \\
\hline Accuracy (\%) & 89 & 92 & 92 & 92 & 81 & 54 & 80 & 89 & 92 & 92 \\
\hline
\end{tabular}

aStimulated calcitonin level taken 2 or 5 min after i.v. bolus injection of pentagastrin, whichever was higher.

${ }^{\mathrm{b}}$ Conversion factor proposed by Bieglmayer et al. (2007), which may be less relevant for calcitonin concentrations $>100 \mathrm{pg} / \mathrm{ml}$.

Converted calcitonin levels $>100 \mathrm{pg} / \mathrm{ml}$ are parenthesized to indicate this fact.

the respective positive predictive values for medullary thyroid cancer at these calcitonin thresholds were merely 89 and $90 \%$ (Tables 3 and 4, left panel), as opposed to $100 \%$ for men (Tables 3 and 4, right panel). This means that as many as 11 and $10 \%$ of women displaying calcitonin levels above these thresholds may not have medullary thyroid cancer. To raise the positive predictive value for women to $100 \%$, the basal and stimulated peak calcitonin thresholds would have to be moved from $15 \mathrm{pg} / \mathrm{ml}$ (corrected $20 \mathrm{pg} / \mathrm{ml}$ ) to $40 \mathrm{pg} / \mathrm{ml}$ (corrected $50 \mathrm{pg} / \mathrm{ml}$; Table 3, left panel), and from $80 \mathrm{pg} / \mathrm{ml}$ (corrected $100 \mathrm{pg} / \mathrm{ml}$ to $250 \mathrm{pg} / \mathrm{ml}$; Table 4, left panel). Altogether, these basal calcitonin thresholds were 1.5- to fourfold (women) and eightfold (men), and the corresponding stimulated peak calcitonin thresholds eight- to 25-fold (women) and 50-fold (men) the respective upper normal limit of the calcitonin assay.

\section{Discussion}

This is the first series exploring gender-specific thresholds in patients with increased basal and stimulated calcitonin levels to differentiate between sporadic C-cell hyperplasia and occult sporadic medullary thyroid cancer. In these elusive conditions, calcitonin levels overlap widely so that the incremental diagnostic value of calcitonin screening is most evident in this setting (Borget et al. 2007).

\section{Gender-specific disparities in calcitonin secretion}

The most striking finding of this series was the four- to eightfold lower yield of medullary thyroid cancer for men in the lower calcitonin segment $(\leq 50 \mathrm{pg} / \mathrm{ml})$. Because male thyroids harbor more $\mathrm{C}$-cells than female thyroids, serum calcitonin levels are more often higher in men than women (Heath \& Sizemore 1977, Hahm et al. 2001, Vierhapper et al. 2005, Weinhaeusel et al. 2008, Rink et al. 2009, Scheuba et al. 2009). This observation explains why men outnumbered women in the sporadic C-cell hyperplasia group by more than eightfold ( 66 men versus 8 women; $P<0.001$ ), whereas women predominated twofold in the occult medullary thyroid cancer group (18 women versus 8 men; Table 1). Similar gender-specific disparities have been reported elsewhere (Rink et al. 2009, Scheuba et al. 2009).

In this study, increased basal calcitonin levels of $\leq 50 \mathrm{pg} / \mathrm{ml}$ for men were associated with much poorer positive predictive values for occult medullary thyroid cancer. It seems that occult medullary thyroid cancers have greater difficulties in men than women to release those quantities of calcitonin into the bloodstream necessary to overcome the background noise of basal calcitonin secretion. As a corollary, all calcitonin thresholds were consistently higher for men than women. Stimulation with pentagastrin afforded better discrimination between C-cell hyperplasia and medullary thyroid cancer in both women and men, especially when calcitonin levels were lower, as noted previously (Iacobone et al. 2002, Karges et al. 2004, Vierhapper et al. 2005, Costante et al. 2007, Scheuba et al. 2009). By implication, pentagastrin stimulation should ideally be performed in all patients with increased basal calcitonin levels unless these levels are high. Of note, pentagastrin has become restricted in some countries.

\section{Calcitonin thresholds in the literature}

Despite the use of diverse selection criteria and different calcitonin assays in heterogeneous populations with variable degrees of histopathologic 
confirmation, there is universal agreement regarding the following statements:

(a) a basal calcitonin level within normal limits of the assay practically excludes medullary thyroid cancer (Elisei et al. 2004, Rink et al. 2009, Scheuba et al. 2009)

(b) the likelihood of medullary thyroid cancer is remote when stimulated calcitonin levels are $<100 \mathrm{pg} / \mathrm{ml}$ (Hahm et al. 2001, Karges et al. 2004, Vierhapper et al. 2005, Rink et al. 2009, Scheuba et al. 2009)

(c) raising calcitonin thresholds lowers the rate of false positives at the cost of missing more subclinical disease (Iacobone et al. 2002, Karges et al. 2004, Vierhapper et al. 2005, Costante et al. 2007, Cheung et al. 2008, Rink et al. 2009).

Traditionally, calcitonin thresholds, most of which differ slightly between institutions, have been conceived as less-than-perfect static means of balancing the consequences of overtreatment and undertreatment. A more dynamic concept consisting of gender-specific relative (20 and $100 \mathrm{pg} / \mathrm{ml}$ for women) and absolute (50 and $250 \mathrm{pg} / \mathrm{ml}$ for women; 100 and $500 \mathrm{pg} / \mathrm{ml}$ for men) basal and stimulated peak calcitonin thresholds may yield greater accuracy and flexibility: close biochemical surveillance for the crossing of the relative threshold; immediate thyroidectomy for the breach of the absolute threshold.

\section{Clinical work-up for sporadic C-cell disease}

Calcitonin serum levels, representing a biologic continuum like any other biomarker levels, should always be interpreted within the clinical context. This involves consideration of thyroid nodules and/or suspect cervical lymph nodes visualizing on highresolution ultrasonography and appreciation of suspicious or positive fine-needle aspiration cytology results using immunohistochemistry for calcitonin and determination of calcitonin in the washout of the needle. For occult medullary thyroid cancer, however, there is a dearth of information on the accuracy and utility of these diagnostic methods, which have been shown to work well in more advanced disease. An association between C-cell hyperplasia and thyroiditis or thyroid autoantibodies, which were not measured in this study, is controversial. As a matter of fact, no statistically significant correlations were found a) between the presence of C-cell hyperplasia and chronic lymphocytic thyroiditis on thyroid surgical specimens from 112 patients (Guyetant et al. 1994), and b) basal calcitonin serum levels and anti-thyroid peroxidase or anti-thyroglobulin antibodies among 298 age-matched hypothyroid or euthyroid goitrous women (Pantazi \& Papapetrou 1998). In keeping, the prevalence of histopathologically diagnosed thyroiditis in this series was broadly comparable among patients with C-cell hyperplasia and lower calcitonin serum levels, and patients with medullary thyroid cancer and higher calcitonin serum levels (Table 1).

\section{Clinical implications}

Because it represents an innocuous intervention with relatively low resource consumption, calcitonin measurement is a powerful tool for detecting $\mathrm{C}$ cell disease at a stage when it is still curable. Although the ultimate proof of a screening test's value lies in the degree to which it extends the survival of those who submit to it, it may take decades for such an extension of life to show statistically. To augment the costeffectiveness of calcitonin screening, its methodology must be refined. Although recent European and American cost-benefit studies have hailed calcitonin screening as cost-effective for patients with nodular goiter (Borget et al. 2007, Cheung et al. 2008), there is still room for improvement. A dynamic concept of gender-specific calcitonin thresholds attuned to the inherent risk of medullary thyroid cancer would help to reduce the unavoidable harms of screening by minimizing the numbers of false positives and unnecessary operations. These false positives have enormous clinical and economic potential for damage: if allowed to spiral out of control, they expand human suffering and inevitably drive up costs, damaging and ultimately destroying the cost-effectiveness of any screening program.

\section{Declaration of interest}

The authors declare that there is no conflict of interest that could be perceived as prejudicing the impartiality of the research reported.

\section{Funding}

This research did not receive any specific grant from any funding agency in the public, commercial, or non-for-profit sector.

\section{Acknowledgements}

The authors are indebted to the physicians and institutions involved in the care of our patients for contributing valuable information. 


\section{References}

Bieglmayer C, Vierhapper H, Dudczak R \& Niederle B 2007 Measurement of calcitonin by immunoassay analyzers. Clinical Chemistry and Laboratory Medicine 45 662-666.

Borget I, de Pouvourville G \& Schlumberger M 2007 Editorial: calcitonin determination in patients with nodular thyroid disease. Journal of Clinical Endocrinology and Metabolism 92 425-427.

Cheung K, Roman SA, Wang TS, Walker HD \& Sosa JA 2008 Calcitonin measurement in the evaluation of thyroid nodules in the United States: a cost-effectiveness and decision analysis. Journal of Clinical Endocrinology and Metabolism 93 2173-2180.

Costante G, Meringolo D, Durante C, Bianchi D, Nocera M, Tumino S, Crocetti U, Attard M, Maranghi M, Torlontano M et al. 2007 Predictive value of serum calcitonin levels for preoperative diagnosis of medullary thyroid carcinoma in a cohort of 5817 consecutive patients with thyroid nodules. Journal of Clinical Endocrinology and Metabolism 92 450-455.

Dralle H 2002 Lymph node dissection and medullary thyroid carcinoma. British Journal of Surgery 89 1073-1075.

Elisei R, Bottici V, Luchetti F, Di Coscio G, Romei C, Grasso L, Miccoli P, Iacconi P, Basolo F, Pinchera A et al. 2004 Impact of routine measurement of serum calcitonin on the diagnosis and outcome of medullary thyroid cancer: experience in 10,864 patients with nodular thyroid disorders. Journal of Clinical Endocrinology and Metabolism 89 163-168.

Guyetant S, Wion-Barbot N, Rousselet MC, Franc B, Bigorgne JC \& Saint-Andre JP 1994 C-cell hyperplasia associated with chronic lymphocytic thyroiditis: a retrospective quantitative study of 112 cases. Human Pathology 25 514-521.

Hahm JR, Lee MS, Min YK, Lee MK, Kim KW, Nam SJ, Yang JH \& Chung JH 2001 Routine measurement of serum calcitonin is useful for early detection of medullary thyroid carcinoma in patients with nodular thyroid diseases. Thyroid 11 73-80.

Heath H \& Sizemore GW 1977 Plasma calcitonin in normal man. Differences between men and women. Journal of Clinical Investigation 60 1135-1140.

Hinze R, Holzhausen HJ, Gimm O, Dralle H \& Rath FW 1998 Primary hereditary medullary thyroid carcinoma C-cell morphology and correlation with preoperative calcitonin levels. Virchows Archiv 433 203-208.

Iacobone M, Niccoli-Sire P, Sebag F, De Micco C \& Henry JF 2002 Can sporadic medullary thyroid carcinoma be biochemically predicted? Prospective analysis of 66 operated patients with elevated serum calcitonin levels World Journal of Surgery 26 886-890.

Karges W, Dralle H, Raue F, Mann K, Reiners C, Grussendorf M, Hüfner M, Niederle B, Brabant G \& German Society for Endocrinology (DGE) - Thyroid Section 2004 Calcitonin measurement to detect medullary thyroid carcinoma in nodular goiter: German evidencebased consensus recommendation. Experimental and Clinical Endocrinology \& Diabetes 112 52-58.

Machens A, Gimm O, Ukkat J, Hinze R, Schneyer U \& Dralle H 2000a Improved prediction of calcitonin normalization in medullary thyroid carcinoma patients by quantitative lymph node analysis. Cancer 88 1909-1915.

Machens A, Haedecke J, Holzhausen HJ, Thomusch O, Schneyer U \& Dralle H $2000 b$ Differential diagnosis of calcitonin-secreting neuroendocrine carcinoma of the foregut by pentagastrin stimulation. Langenbeck's Archives of Surgery 385 398-401.

Machens A, Niccoli-Sire P, Hoegel J, Frank-Raue K, van Vroonhoven TJ, Röher HD, Wahl RA, Lamesch P, Raue F, Conte-Devolx B et al. 2003 Early malignant progression of hereditary medullary thyroid cancer. New England Journal of Medicine 349 1517-1525.

Machens A, Schneyer U, Holzhausen HJ \& Dralle H 2005 Prospects of remission in medullary thyroid carcinoma according to basal calcitonin level. Journal of Clinical Endocrinology and Metabolism 90 2029-2034.

Machens A, Hofmann C, Hauptmann S \& Dralle H 2007 Locoregional recurrence and death from medullary thyroid carcinoma in a contemporaneous series: 5-year results. European Journal of Endocrinology 157 85-93.

Oskam IM, Hoebers F, Balm AJM, van Coevorden F, Bais EM, Hart AM \& van den Brekel MW 2008 Neck management in medullary thyroid carcinoma. European Journal of Surgical Oncology 34 71-76.

Pantazi H \& Papapetrou PD 1998 Calcitonin levels are similar in goitrous euthyroid patients with or without thyroid antibodies, as well as in hypothyroid patients. European Journal of Endocrinology 138 530-535.

Rink T, Truong PN, Schroth HJ, Diener J, Zimny M \& Grünwald F 2009 Calculation and validation of a plasma calcitonin limit for early detection of medullary thyroid carcinoma in nodular thyroid disease. Thyroid 19327-332.

Scheuba C, Kaserer K, Moritz A, Drosten R, Vierhapper H, Bieglmayer C, Haas OA \& Niederle B 2009 Sporadic hypercalcitoninemia. Clinical and therapeutic consequences. Endocrine-Related Cancer 16 243-253.

Scollo C, Baudin E, Travagli JP, Caillou B, Bellon N, Leboulleux S \& Schlumberger M 2003 Rationale for central and bilateral lymph node dissection in sporadic and hereditary medullary thyroid cancer. Journal of Clinical Endocrinology and Metabolism 88 2070-2075.

Vierhapper H, Niederle B, Bieglmayer C, Kaserer K \& Baumgartner-Parzer S 2005 Early diagnosis and curative therapy of medullary thyroid carcinoma by routine measurement of serum calcitonin in patients with thyroid disorders. Thyroid 15 1267-1272.

Weinhaeusel A, Scheuba C, Lauss M, Kriegner A, Kaserer K, Vierlinger K, Haas OA \& Niederle B 2008 The influence of gender, age, and RET polymorphisms on C-cell hyperplasia and medullary thyroid carcinoma. Thyroid $\mathbf{1 8}$ 1269-1276. 